\title{
Assessment of a terrestrial protected area for the conservation of freshwater biodiversity
}

\author{
Joana Garrido Nogueira ${ }^{1,2}$ () | Amílcar Teixeira ${ }^{3}$ | Simone Varandas ${ }^{4}$ | \\ Manuel Lopes-Lima ${ }^{2}$ ( ) | Ronaldo Sousa ${ }^{1}$
}

${ }^{1}$ CBMA - Centre of Molecular and Environmental Biology, Department of Biology, University of Minho, Braga, Portugal

${ }^{2} \mathrm{CIBIO} / \mathrm{InBIO}$ - Research Center in Biodiversity and Genetic Resources, University of Porto, Vairão, Portugal

${ }^{3}$ Centro delnvestigação de Montanha (CIMO), Instituto Politécnico de Bragança, Bragança, Portugal

${ }^{4}$ CITAB-UTAD - Centre for Research and Technology of Agro-Environment and Biological Sciences, University of Trás-osMontes and Alto Douro, Vila Real, Portugal

\section{Correspondence}

Joana Garrido Nogueira, CBMA - Centre of Molecular and Environmental Biology, Department of Biology, University of Minho, Campus Gualtar, 4710-057 Braga, Portugal.

Email: joanafgnogueira93@gmail.com

Funding information

Programa Operacional Sustentabilidade e Eficiência no Uso dos Recursos (POSEUR-032215-FC-000096)

\begin{abstract}
1. Freshwater ecosystems are essential to human well-being and most have high biodiversity. However, this biodiversity has been suffering severe declines owing to the expansion of human activities. Protected areas (PAs) are essential for biodiversity conservation and have proved to be successful in stopping species extirpation if managed properly. Unfortunately, they are usually focused on terrestrial biodiversity, leaving freshwater ecosystems aside.
\end{abstract}

2. The main goal of this study was to determine the influence of a PA (Montesinho Natural Park (MNP), Portugal) on freshwater biodiversity. Aquatic macroinvertebrates and fishes were surveyed, and biodiversity (richness, abundance, Shannon-Wiener diversity, and Pielou's evenness) and water quality (IASPT) indices were calculated inside, at the periphery and outside the MNP.

3. Results showed that the PA does not affect positively either water quality or the two faunal groups monitored. Macroinvertebrate communities were not influenced by the PA; however, the abundance of pearl mussel Margaritifera margaritifera was significantly higher and size was significantly lower inside the MNP. The richness and abundance of fish communities were significantly higher outside the MNP, except for trout Salmo trutta abundance which was higher inside the MNP.

4. Given these results, the MNP does not guarantee the safeguard of overall aquatic biodiversity and habitats and we propose an extension of MNP to downstream areas in order to increase the number of species (mostly cyprinids) under legal protection. This work demonstrates that terrestrial PA planning and management should also consider aquatic biodiversity to achieve successful conservation.

\section{KEYWORDS}

biodiversity, fish, invertebrates, river

\section{1 | INTRODUCTION}

Freshwater ecosystems are essential for environmental health, economic wealth and human well-being (Grill et al., 2019). Covering approximately $1 \%$ of the Earth's surface, lakes and rivers host $9.5 \%$ of all animal species (Dudgeon et al., 2006; Dudgeon, 2019; He et al., 2019), making freshwater ecosystems areas of high biodiversity.
Nevertheless, freshwater biodiversity faces numerous threats responsible for large declines in abundance and spatial distribution of many species (Reid et al., 2019). For example, 44\% of freshwater mussels, $37 \%$ of fish, $23 \%$ of amphibians, $15 \%$ of dragonflies and $7 \%$ of aquatic plants are threatened in Europe (Temple \& Cox, 2009; Kalkman et al., 2010; Bilz et al., 2011; Cuttelod, Seddon \& Neubert, 2011; Freyhof \& Brooks, 2011). Several freshwater species suffered 
pronounced range contractions, like the European sturgeon (Acipenser sturio Linnaeus, 1758) that was extirpated from almost all major European rivers (Williot et al., 2009). Given the remarkable biodiversity, high vulnerability and high levels of endemism present in freshwater ecosystems, these areas should be considered a conservation priority (Darwall et al., 2011; Dudgeon, 2019).

A variety of measures are available to manage freshwater ecosystems and address biodiversity decline, from local river restoration to the large-scale implementation of protected areas (PAs) (Gray et al., 2016; Pimm, Jenkins \& Li, 2018). Given the potential role of PAs in preserving biodiversity, important freshwater ecosystems have been the main targets for worldwide conservation. Examples include the European Union's Special Areas of Conservation developed to protect rare and vulnerable species under the European Habitats Directive (Council of the European Communities, 1992); Ramsar Sites (e.g. Lake Baikal in Russia, Danube Delta in Romania); and Key Biodiversity Areas developed to protect wetlands (Saunders, Meeuwig \& Vincent, 2002; Butchart et al., 2015). Despite this increasing interest in freshwater conservation, there is still a high discrepancy in the total PA coverage between freshwater and marine and terrestrial systems (Juffe-Bignoli et al., 2014). This could be partially explained by the fact that the implementation of management measures in PAs is much more developed for terrestrial and marine ecosystems (Collier, 2011). The difficulties in protecting freshwater biodiversity are generally related to the intricate complexity of river connections, the spatial and temporal variability of freshwater habitats, the lack of control of external processes and threats and patchy information on freshwater species (Roux et al., 2008; Abell et al., 2011; Collier, 2011; Darwall et al., 2011). Furthermore, rivers are often chosen as simple administrative boundaries of PAs (e.g. the Tejo River in Portugal is used to delineate the Tejo International Natural Park). In addition, the hydrological connectivity in a river (longitudinal, lateral and vertical) also poses a great challenge for the design of PAs, so the approaches used in terrestrial ecosystems are not always adequate for freshwater protection (Abell, Allan \& Lehner, 2007).

Given these problems, numerous rare or endemic species in freshwater ecosystems lack representation for justifying new PAs (Hermoso et al., 2015a). Also, there are mixed results concerning the successful implementation of PAs to protect freshwater biodiversity. Some studies show positive results Sanyanga, Machena \& Kautsky, 1995; Baird \& Flaherty, 2005; Cucherousset et al., 2007; Keppler, Hallwass \& Silvano, 2017), others report no differences in biodiversity patterns outside and inside PAs (Heino et al., 2009; Srinoparatwatana \& Hyndes, 2011) and others even display negative effects (Norris, Michalski \& Gibbs, 2018). To the best of our knowledge there has been no such assessment (i.e. positive, negative or neutral effects of PAs in freshwater biodiversity using empirical data) in Portugal, (but see Araújo, Lobo \& Moreno, 2007, for terrestrial biodiversity and Hermoso et al., 2015b, for aquatic biodiversity, both studies using presence/absence data). In addition, most studies that assess the relevance of PAs mostly focus on 'outside' vs. 'inside' comparisons, neglecting the importance of the edge effect (Herremans \&
Herremans-Tonnoeyr, 2000). These border areas represent contact zones between protected and unprotected areas containing a vast range of interactions between nature and people (Blanco et al., 2019) and biodiversity should also be evaluated here.

Assuming the uncertainty about the possible positive (neutral or even negative) influence of terrestrial PAs, this study aimed to assess whether the protection afforded by the Montesinho Natural Park (MNP), in north-east Portugal, influences freshwater biodiversity. For this, two faunal groups (macroinvertebrates and fishes), as well as environmental data, were sampled inside, outside and at the periphery of the MNP. Macroinvertebrate communities are very diverse and abundant, playing an important role in freshwater ecosystems as an energy link between different trophic levels (Covich et al., 1999). Among the macroinvertebrates sampled, special attention was given to the freshwater pearl mussel Margaritifera margaritifera (Linnaeus, 1758), owing to their conservation status (i.e. listed as Critically Endangered in Europe) (Moorkens et al., 2018). Fish communities were also sampled and studied because of their ecological role, conservation and cultural relevance (Closs, Krkosek \& Olden, 2015). We hypothesized that if the PA is safeguarding freshwater biodiversity (besides terrestrial biodiversity), it would be expected that improved environmental conditions and freshwater biodiversity will be found inside the MNP.

\section{2 | METHODS}

\section{1 | Study area}

MNP was created in 1979 , has an area of 75,000 ha and is located in Trás-os-Montes region, north-east Portugal. The park has high biodiversity when compared with other Portuguese PAs and was mainly established with the focus on protecting birds, terrestrial vertebrates and plants (Cabrita, Cunha \& Henriques, 2000).

Climate is typically Mediterranean with influence from the Atlantic Ocean, with annual average temperature varying between 8.5 and $12.8^{\circ} \mathrm{C}$ and annual average precipitation between 1,000 and $1,600 \mathrm{~mm}$ (Oliveira et al., 2012). The geology of the park is dominated by schist, granite, amphibolite, and migmatite, with altitude ranging between 438 and 1,481 $\mathrm{m}$.

Land use in the study area is relatively homogeneous, mostly related to forest and agricultural activities (Corine Land Cover, 2020). The human population in the study area is low, totalling 9,000 inhabitants mainly devoted to subsistence agriculture. Rivers surveyed in this study are included in the Tua (Mente, Rabaçal and Tuela rivers) and Sabor (Sabor River) basins with areas of $3,813 \mathrm{~km}^{2}$ and $3,868 \mathrm{~km}^{2}$, respectively. Mente is a tributary of Rabaçal, which in turn is connected to Tuela to form the Tua River. All the four rivers originate in Spain with lengths of $57,88,102$, and $120 \mathrm{~km}$, respectively, all belonging to the Douro basin. All sites surveyed are first-order rivers (Strahler, 1964) with the exception of downstream sites in the Tuela River (T1 and T2) that belong to the second order. Substrate size in the study area is very similar, being dominated by gravel (approximately 
80\%) and sand (approximately 19\%) (Sousa et al., 2020). The rivers are in good environmental condition owing to low human pressure although there is some organic pollution in downstream areas of the Tuela River (Sousa et al., 2012; Sousa et al., 2020).

The rivers that cross the MNP are important habitats for brown trout Salmo trutta Linnaeus, 1758, and Iberian endemic cyprinids such as Squalius carolitertii (Doadrio, 1988), Luciobarbus bocagei (Steindachner, 1864), with Pseudochondrostoma duriense (Coelho, 1985), Achondrostoma arcasii (Steindachner, 1866), and Squalius alburnoides (Steindachner, 1866) considered Vulnerable in the IUCN Red List of Threatened Species (https://www.iucnredlist.org). Other threatened freshwater species listed in the IUCN Red List include the pearl mussel M. margaritifera (Endangered), the freshwater mussel Potomida littoralis (Cuvier, 1798) (Endangered), the Iberian loach Cobitis calderoni Băcescu, 1962 (Endangered), the dragonfly Macromia splendens Pictet, 1843 (Vulnerable), and the Iberian desman Galemys pyrenaicus (É. Geoffroy Saint-Hilaire, 1811) (Vulnerable). Non-native invasive species such as the crayfish Pacifastacus leniusculus (Dana, 1852) and the pumpkinseed sunfish Lepomis gibbosus (Linnaeus, 1758) are also present in the study area (Anastácio et al., 2019; Meira et al., 2019; Sousa et al., 2019).

\subsection{Sampling strategy}

Field surveys were carried out between the middle of July and early August 2018, at 24 sampling sites: six sites for each of the four rivers surveyed (Figure 1). Sites with the numbers 1 and 2 correspond to areas outside (pink), 3 and 4 to areas at the periphery (green), and 5 and 6 to areas inside (blue) the MNP. Sites classified as periphery correspond to sites located less than $2 \mathrm{~km}$ from the southern limit of the park. Each site corresponds to a stretch of river with a total length of 50 and $100 \mathrm{~m}$ for invertebrates and fish communities, respectively. For the environmental characterization, water temperature, conductivity, and dissolved oxygen were analysed in situ in the middle of the river and near the bottom in all sites with a $\mathrm{HACH} \mathrm{HQ} 40 \mathrm{~d}$ multi-parameter probe (Hach Company, Colorado, USA). These measurements were always performed at the end of the morning. Channel width and mean depth were measured with a tape.

Macroinvertebrates were sampled using a hand net with a $0.5 \mathrm{~mm}$ mesh and a width of $250 \mathrm{~mm}$. Sampling covered all types of habitats (e.g. lentic and lotic, banks and centre of the channel) and sediments (e.g. pebbles, cobbles, sand, silt, clay, macrophytes). In each site, six replicate samples were taken from areas $1 \mathrm{~m}$ long and $0.25 \mathrm{~m}$ wide. The sampling net was placed downstream while the substratum was moved upstream, pushing the macroinvertebrates into the net. Organisms were stored in the field in labelled flasks containing alcohol (70\%) to be later sorted and identified to the family level. Identification of all organisms was performed with a dissecting microscope using Tachet et al. (2003).

To record the possible presence of freshwater mussels (Order Unionida), different habitats (riffles, pools, near the banks and in the centre of the channel) were also sampled. Individuals were surveyed by snorkelling and hand searching (detailed methodology described in

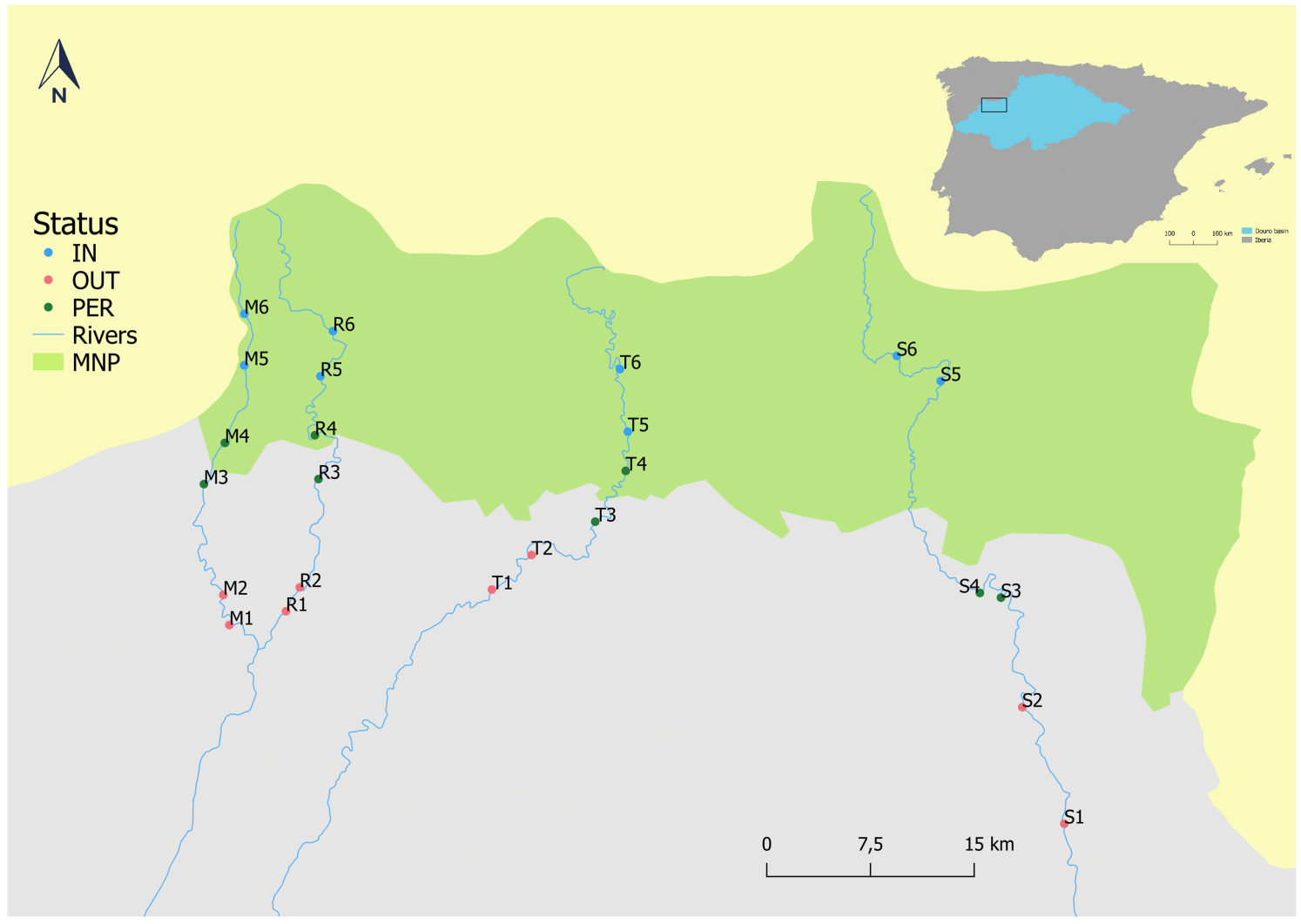

FIGURE 1 Map of the surveyed area showing the location of the 24 sampling sites in Mente (M), Rabaçal (R), Tuela (T) and Sabor (S) Rivers 
Sousa et al., 2013, and Nogueira et al., in press) and four to six replicates were collected at each site. All the live specimens were identified, counted and measured (total length) with a Vernier calliper (to $0.1 \mathrm{~mm}$ ), and returned to their habitat in their original position. Abundance was expressed as the number of individuals per $5 \mathrm{~min}$ of diving - catch per unit effort (CPUE).

Fish were surveyed by electrofishing using portable equipment (Hans Grassl) with a pulsed DC-300-600 V generator, with the sampling time ranging from 20 to $40 \mathrm{~min}$. The stunned fish were collected and identified to the species level, counted and measured (total length) with a ruler. All specimens were released after the collection of these data. Fish abundance was expressed as the number of individuals in a 20-min fish sample - catch per unit effort (CPUE).

\subsection{Data analysis}

Environmental characterization consisted of the analysis of nine variables: water temperature, conductivity, dissolved oxygen, river width and depth (as described above) together with altitude, distance to the nearest village (DNV), distance to the limits of the park (DTP) and Human Footprint Index (HFI). The HFI measures human pressure by compiling information on population density, human land use and infrastructure (e.g. built-up areas, cropland, pasture, and night-time lights) and human access (e.g. roads, railroads, and navigable waterways). Data on HFI were obtained from the most recent update (Venter et al., 2016), and in the particular case of this study, the average percentage value for each sampling site was used. Altitude and DNV were recorded using Google Earth, with DNV considered to be the minimum distance in a straight line from the sampling site to the nearest village. The DTP was measured using QGIS (2.18.26), being the river distance from sampling sites to the nearest limit of MNP, in which positive values relate to sites outside the park, and negative ones to sites inside the park.

All environmental data were normalized to perform a Principal Component Analysis (PCA), ordinating sites on the premise that sites that ordinated together are more similar, based on the environmental factors measured, than sites ordinated far apart. To evaluate the influence of the protection status and the river on the macroinvertebrate and fish communities at the 24 sites, a two-way PERMANOVA was designed (using the Bray-Curtis similarity index) with protection status (three factors: outside, periphery and inside) as a fixed factor and the river (four factors: Mente, Rabaçal, Tuela, and Sabor) as a random factor. All the statistical analyses used the same design in which the protection status is the fixed factor and the river is the random factor in order to avoid the spatial dependency of the sites within the same river. The test considered 9,999 permutations, but when the number was lower than 150 the Monte Carlo test $P$-value was considered. Richness (number of macroinvertebrate families and number of fish species; S), abundance $(\mathrm{N})$, diversity indices Shannon-Wiener $\left(\mathrm{H}^{\prime}\right)$ and Pielou's evenness $\left(\mathrm{J}^{\prime}\right)$ were calculated using the DIVERSE function. All the analyses mentioned above were performed on Primer 6 (version 1.0.3, Primer-E Ltd, Plymouth).
The water quality index IASPT (Iberian Average Score Per Taxa; Alba-Tercedor et al., 2002) was also determined by dividing the IBMWP (Iberian Bio-Monitoring Working Party; Alba-Tercedor \& Sánchez-Ortega, 1988) by the number of macroinvertebrate families present. Differences in S, N, $\mathrm{H}^{\prime}$, J' and IASPT for macroinvertebrates and $\mathrm{H}^{\prime}$ and $\mathrm{J}^{\prime}$ for fishes in response to the protection status were tested by a linear mixed model, and for fishes $\mathrm{N}$ and $\mathrm{S}$ by a generalized linear mixed model with a Poisson distribution. Abundance and length of the pearl mussel M. margaritifera were analysed compiling data for the three rivers in which the species is present (Mente, Rabaçal and Tuela Rivers; see Results). Owing to the non-normality of the data, a generalized linear mixed model (negative binomial distribution) was used to assess possible differences in abundance and length in relation to the protection status. A linear regression tested a possible relationship between pearl mussel abundance and the abundance of its fish host (Salmo trutta).

A more detailed assessment was made for each fish species individually. To test possible differences in the abundance of $S$. trutta and Cobitis paludica (de Buen, 1930) at sites with different protection status, a linear mixed model was applied. Differences in the abundance of S. carolitertii, S. alburnoides, L. bocagei, P. duriense, and C. calderoni, as well as the total length of all fish species in response to the protection status, were assessed using a generalized linear mixed model (negative binomial distribution). Whenever relevant, multiple comparison tests (Tukey) were conducted. All models were selected by an AIC (Akaike Information Criterion) test and statistical analyses were performed with R (R Development Core Team, 2019) package Ime4.

\section{3 | RESULTS}

\section{1 | Environmental characterization}

Detailed environmental characterization in all sampling sites is presented in Table S1 (Supporting Information). Temperature varied between 16.9 (M3) and $24.2^{\circ} \mathrm{C}(\mathrm{S} 1)$; dissolved oxygen between 6.8 (S2) and $8.9 \mathrm{mg} \mathrm{L}^{-1}(\mathrm{M} 4)$; and water conductivity between 38.9 (S6) and 161.2 (S1) $\mu \mathrm{S} \mathrm{cm}^{-1}$; depth between 0.3 (M2, M5, M6, R4, R6, T1, T6 and S6) and $1.5 \mathrm{~m}$ (T4); altitude between 385.0 (R1) and $721.0 \mathrm{~m} \mathrm{(S6)}$; width between 6.0 (M6) and $22.0 \mathrm{~m}$ (S3); DNV between 900.0 (T1) and $3580.0 \mathrm{~m}$ (S2); HFI between 15.0 (S5 and S6) and 50.0\% (T2, S2 and S4) and DTP between 100.0 (T3) and $12,200.0 \mathrm{~m}(\mathrm{~S} 1)$.

Results of the PCA showed a clear distinction between S1, S2, S3 and S4 and all the other sites (Figure 2). PC1 explains $38.1 \%$ of all variation, with the main environmental factors responsible for the separation in PC1 identified as oxygen (positive direction), conductivity and temperature (negative direction). PC2 explains $21.8 \%$ of all variation, with altitude and width (negative direction) and DTP (positive direction) as the main distinctive environmental factors in this axis. The remaining sites differentiate mostly in PC2 reflecting altitude, width, and distance to the park limit. Sites R1, M1, T1, R2, M2, T2, and R3 are located downstream, have lower altitudes and have 


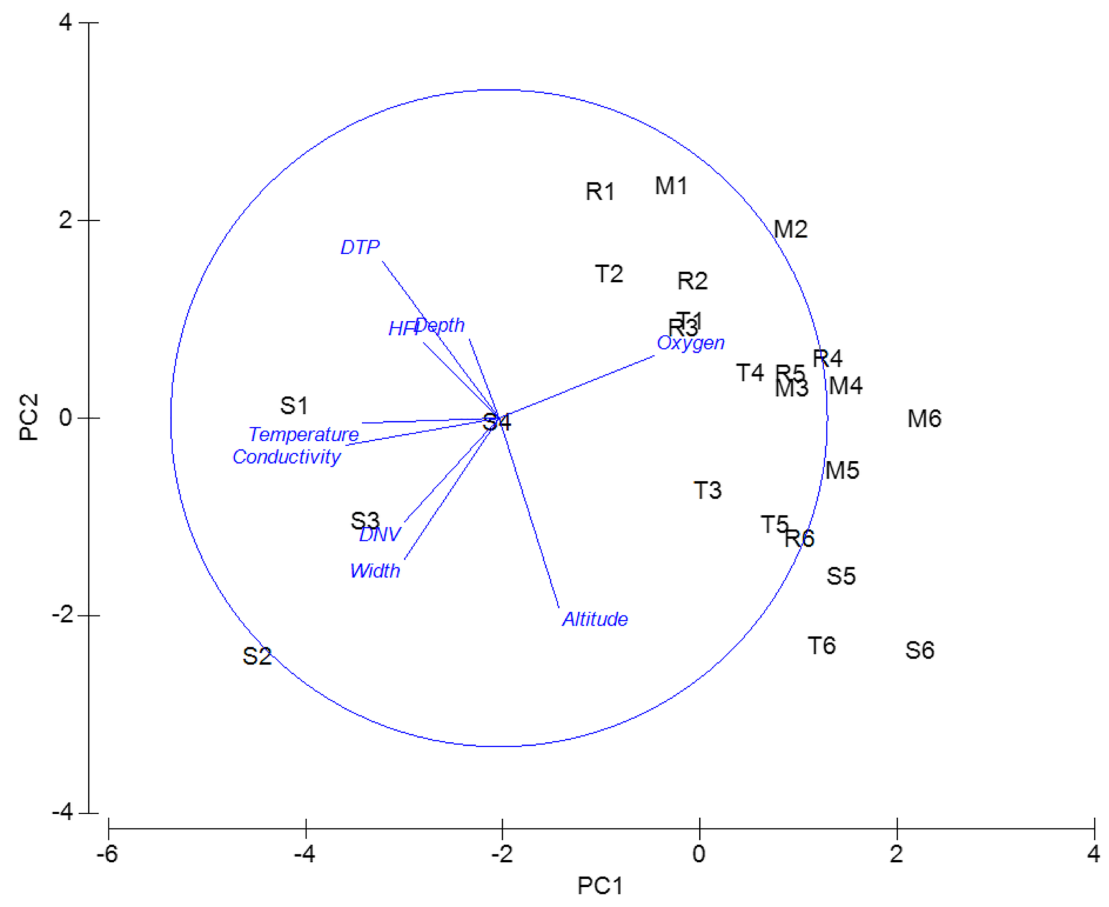

FIGURE 2 Principal components analysis (PCA) showing the arrangement of the 24 sampling sites based on the environmental factors measured. PC1 explains $38.1 \%$ and PC2 $21.8 \%$ of all variance longer channel widths and distance to the park limit when compared with sites T3, T5, T6, M5, R6, S5, and S6. The latter sites are located upstream and are characterized by higher altitudes, narrower channel width and located inside or very near the park limit. Sites R4, R5, M3, M4, M6, and T4 correspond to sites with intermediate environmental characteristics mentioned previously.

\section{2 | Macroinvertebrate communities}

In total, 29,710 individuals belonging to 90 families were identified. PERMANOVA results indicate that there are no significant differences in the macroinvertebrate communities inside, at the periphery and outside the MNP (Pseudo-F = 0.8; $P=0.6$ ). However, there were differences among the rivers (Pseudo- $F=4.1 ; P=0.0001$ ) as well as an interaction between rivers and protection status (Pseudo- $F=2.1$; $P=0.0005)$. Differences inside, at the periphery, and outside the MNP in macroinvertebrate richness were not significant $\left(\chi^{2}=3.1\right.$; $P=0.2)$ (Figure 3a) and the same was true for abundance $\left(\chi^{2}=2.9\right.$; $P=0.2)$ (Figure $3 b)$, Shannon-Wiener $\left(H^{\prime}\right)$ diversity $\left(\chi^{2}=1.1 ; P=0.6\right.$ ) (Figure 3c), Pielou's evenness $\left(\chi^{2}=4.9 ; P=0.08\right.$ ) (Figure $3 \mathrm{~d}$ ) and IASPT ( $\chi^{2}=1.1 ; P=0.6$ ) (Figure 3e).

For the pearl mussel M. margaritifera, 1,222 individuals were found in the Mente, Rabaçal and Tuela rivers. From these, $44.9 \%$ were found inside the park, $33.1 \%$ at the periphery, and $22.0 \%$ outside. Average $( \pm S D)$ abundance of $M$. margaritifera was higher inside the park with $12.5( \pm 18.6)$, followed by the periphery with $8.3( \pm 15.9)$ and outside with $5.9( \pm 10.7)$ CPUE (Figure 4 a) and differences were statistically significant $\left(\chi^{2}=9.9 ; P=0.006\right)$. Average $( \pm S D)$ length varied between $72.3( \pm 12.3)$ outside MNP, $69.9 \mathrm{~mm}( \pm 12.1)$ at the periphery, and $67.6 \mathrm{~mm}( \pm 11.5)$ inside the park (Figure $4 \mathrm{~b}$ ) being significantly different $\left(\chi^{2}=49.9 ; P<0.001\right)$. No relationship was found between pearl mussel abundance and its fish host Salmo trutta abundance $(R=0.45, \mathrm{~F}=3.02, P=0.11)$.

\section{3 | Fish communities}

In total, 2,043 individuals belonging to seven species were surveyed in this study, of which $11.8 \%$ were present inside, $46.6 \%$ at its periphery and $41.6 \%$ outside the MNP. The seven fish species were $S$. trutta, S. carolitertii, P. duriense, S. alburnoides, L. bocagei, C. calderoni, and C. paludica. PERMANOVA results detected significant differences in fish communities inside, at the periphery and outside the MNP (Pseudo- $\mathrm{F}=4.7 ; P=0.02$ ) with all status being significantly different from each other, as well as among the different rivers (Pseudo$F=3.7 ; P=0.003$ ) with an interaction between the two factors (Pseudo-F = 2.5; $P=0.002$ ).

Average $( \pm S D)$ species richness was highest outside, with 4.8 species $( \pm 0.7)$, followed by the periphery with $4.3( \pm 1.3)$, and inside, with $3.0( \pm 0.9)$ (Figure 5a) with significant differences detected $\left(\chi^{2}=13.1 ; P=0.001\right)$. The periphery had the highest average $( \pm S D)$ value of fish abundance with 119.0 ( \pm 150.3$)$, followed by outside, with 106.1 ( \pm 84.2 ), and inside with $30.3( \pm 28.1)$ CPUE (Figure $5 \mathrm{~b}$ ) with significant differences also detected $\left(\chi^{2}=372.2 ; P<0.001\right)$. ShannonWiener diversity values were not significantly affected by the MNP status $\left(\chi^{2}=3.2 ; P=0.2\right)$ (Figure $5 c$ ) and the same was true for Pielou's evenness $\left(\chi^{2}=2.3 ; P=0.3\right.$ ) (Figure $5 d$ ).

Possible differences in abundance (Figure S1, Supporting Information) and length (Figure S2, Supporting Information) were also assessed for each fish species. Salmo trutta abundance differed significantly between protection status $\left(\chi^{2}=14.3 ; P=0.0007\right)$, being less 
FIGURE 3 Richness (a), abundance (CPUE) (b), Shannon-Wiener diversity (c), Pielou's evenness (d) and IASPT water quality index (e) of the macroinvertebrate communities outside the park (O-pink), at the periphery ( $\mathrm{P}$-green) and inside the park (I-blue). White circles represent the average values. Boxplots show median values (central line), the range from the 25th to 75th percentile (box) and the largest and lowest value within $1.5 x$ the interquartile range below and above the 25th and 75th percentile (whiskers). Dots represent extreme values
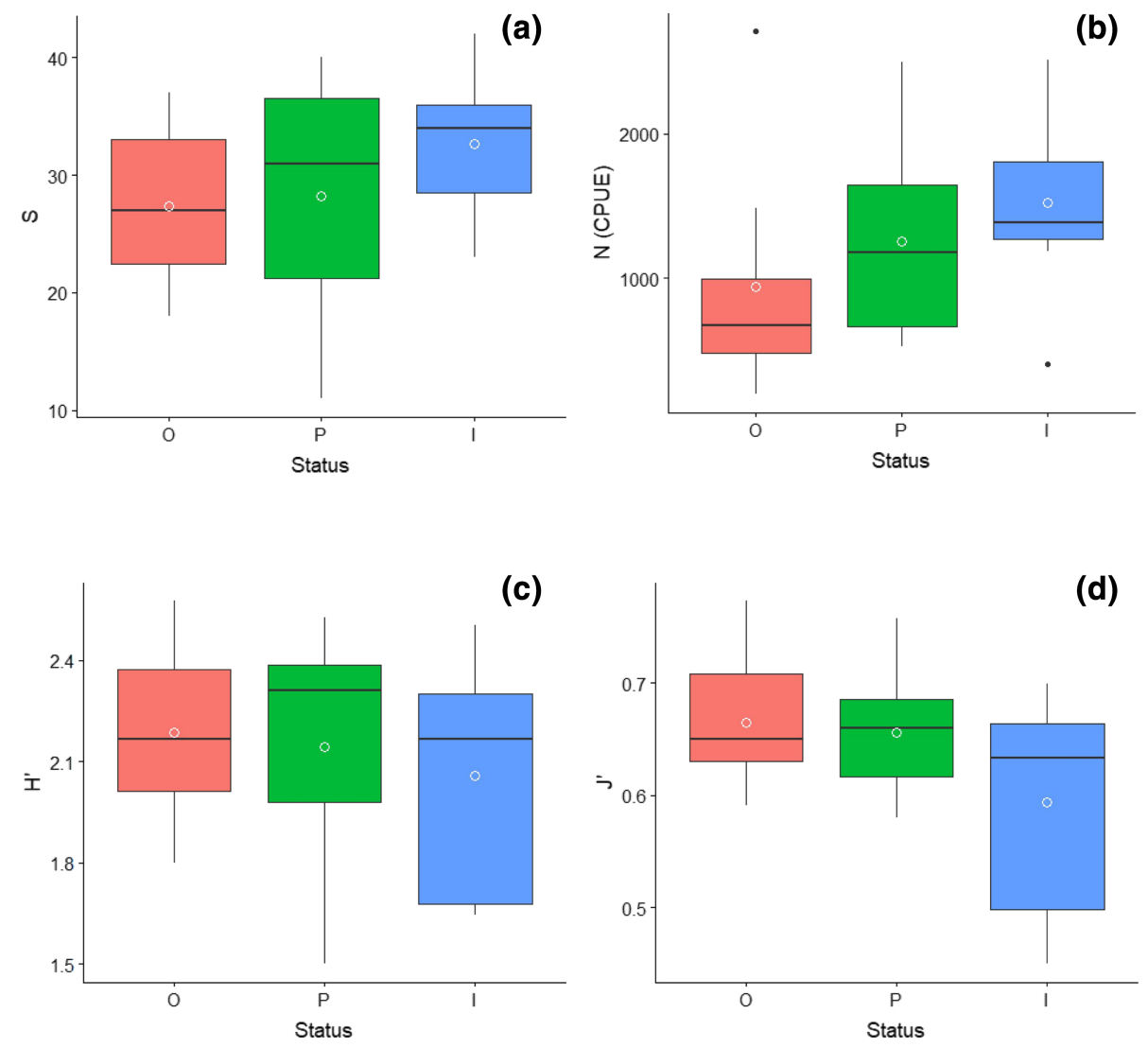

(d)

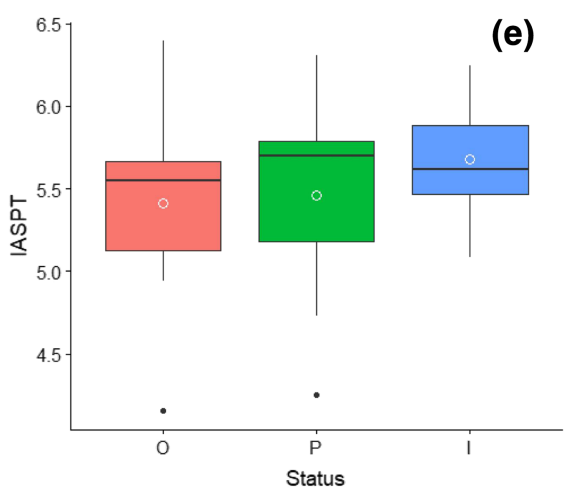

(a)

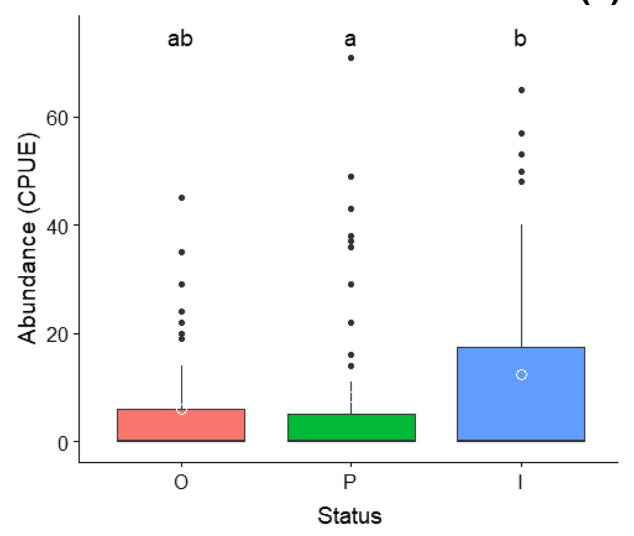

(b)

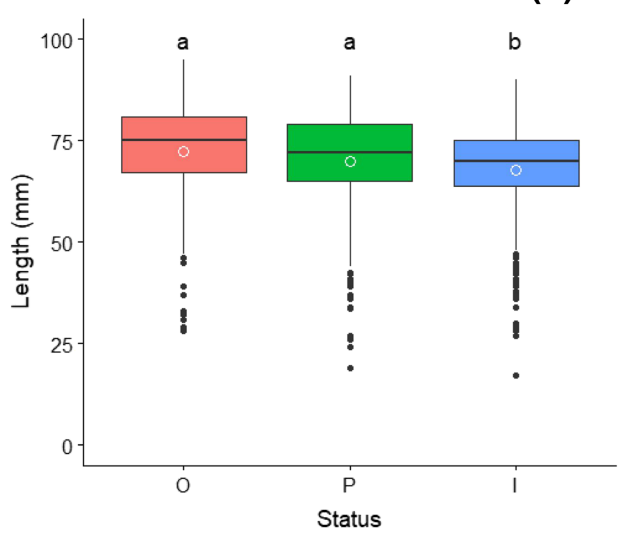

(b)
FIGURE 4 Abundance (CPUE) (a) and length $(\mathrm{mm})(\mathrm{b})$ of pearl mussel Margaritifera margaritifera outside the park (O-pink), at the periphery ( $\mathrm{P}$ green) and inside the park (I-blue). White circles represent the average values. Boxplots show median values (central line), the range from the 25th to 75 th percentile (box) and the largest and lowest value within 1.5 times the interquartile range below and above the 25th and 75th percentile (whiskers). Dots represent extreme values. Different letters indicate significant differences among status 


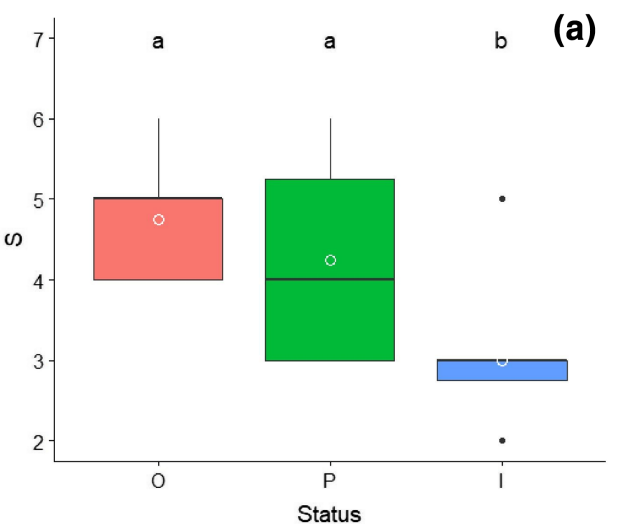

(c)

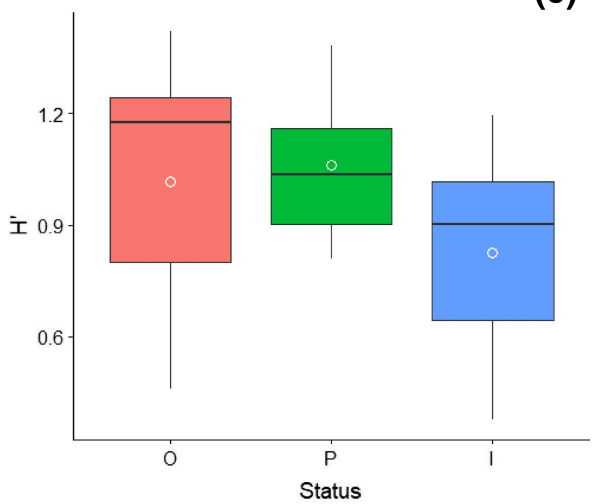

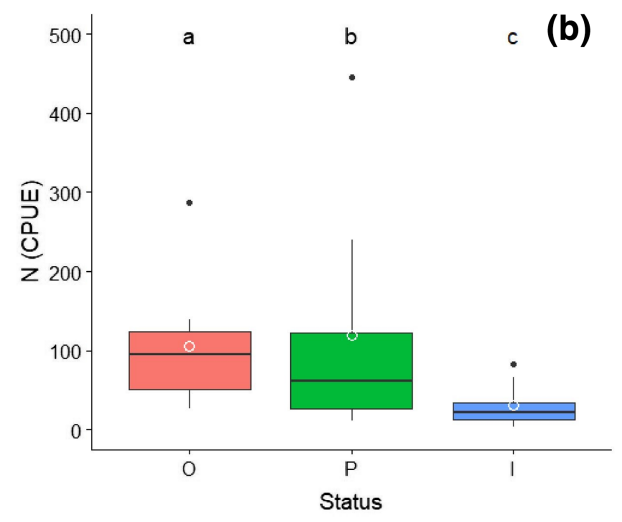

(d)

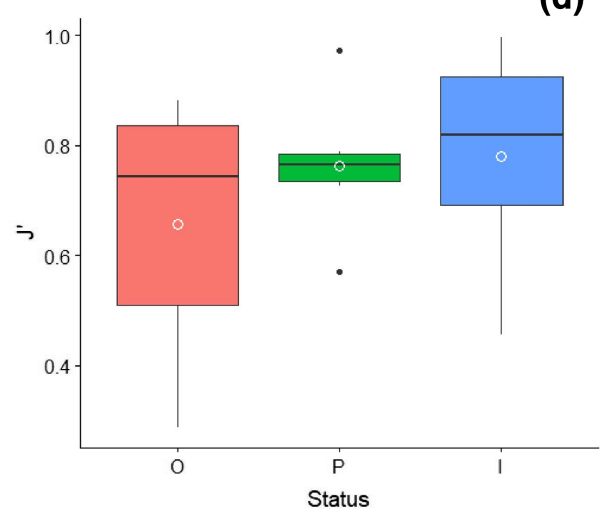

FIGURE 5 Richness (a), abundance (CPUE) (b), ShannonWiener diversity (c) and Pielou's evenness (d) of the fish communities outside the park (O-pink), at the periphery ( $\mathrm{P}$-green) and inside the park (I-blue). White circles represent the average values. Boxplots show median values (central line), the range from the 25th to 75th percentile (box) and the largest and lowest value within 1.5 times the interquartile range below and above the 25th and 75th percentile (whiskers). Dots represent extreme values. Different letters indicate significant differences among status abundant outside the PA. In contrast, $P$. duriense $\left(\chi^{2}=28.4 ; P<0.001\right)$ was less abundant inside the MNP. No significant differences were detected in S. alburnoides $\left(\chi^{2}=0.1 ; P=0.1\right)$ and $C$. paludica $\left(\chi^{2}=3.9\right.$; $P=0.1$ ) abundance between the periphery and outside the park, given that these species were not found inside the MNP. The abundance of L. bocagei was not influenced by the protection status $\left(\chi^{2}=3.6\right.$; $P=0.2)$ and the same was true for $S$. carolitertii $\left(\chi^{2}=1.1 ; P=0.6\right)$ and C. calderoni $\left(\chi^{2}=0.1 ; P=0.9\right)$. With respect to the length of each fish species by protection status, significant differences were found in S. alburnoides $\left(\chi^{2}=21.4 ; P<0.001\right)$ that is smaller at the periphery, and L. bocagei $\left(\chi^{2}=55.4 ; P<0.001\right)$, $P$. duriense $\left(\chi^{2}=9.3 ; P<0.001\right)$ and $C$. paludica $\left(\chi^{2}=112 ; P<0.001\right)$ that are larger outside the MNP. No significant differences in the length of $S$. trutta $\left(\chi^{2}=0.3 ; P=0.9\right)$, S. carolitertii $\left(\chi^{2}=0.5 ; P=0.8\right)$ and $C$. calderoni $\left(\chi^{2}=0.2 ; P=0.9\right)$ were observed between the PA and elsewhere.

\section{4 | DISCUSSION}

Overall, results showed that MNP does not positively affect either the water quality or the macroinvertebrate and fish communities, with the exception of M. margaritifera and S. trutta. In fact, for the fish communities, species richness and abundance were higher outside the MNP. This situation (no positive effect of the PA on freshwater biodiversity) is probably a reflection of the lack of representation of aquatic species in the design of MNP that was mainly created to protect terrestrial biodiversity. The outcomes of this study are consistent with others
(Herbert et al., 2010) and show another example of the deficiency in protecting aquatic imperilled fauna in Europe (Maceda-Veiga et al., 2017). For example, Hermoso et al. (2015b) demonstrated that the Natura 2000 Network (Council of the European Communities, 1992) fails to protect aquatic species in Iberian catchments. Similarly, Walters et al. (2019) showed that $95 \%$ of the hotspots (richness and endemicity) for fish were located outside PAs in Texas (USA). A recent review (Acreman et al., 2019) reported mixed results about the efficiency of PAs for freshwater biodiversity: out of 75 case studies, 38 showed a positive effect, 25 a neutral effect, and 12 a negative effect on freshwater biodiversity. However, caution is needed when interpreting these results as most published studies use only distributional or presence/absence data to compare the ecological state of rivers inside and outside PAs, with few studies assessing richness, abundance, and diversity indices in response to protection status.

\section{1 | Environmental characterization}

Sites S1, S2, S3, and S4 were different from all other sites. This may result from the greater influence of the Mediterranean climate in the middle and lower parts of the Sabor River, translated into the higher water temperature and conductivity, and lower dissolved oxygen (Sousa et al., 2012). In addition, these four sites had wider channels and are subject to higher HFI owing to the proximity of roads, more dense human populations, and more intense 
agricultural activities. Although not quantitatively evaluated in the present study, earlier assessments showed that all rivers have very similar sedimentological conditions (coarse sediments typical of mountainous rivers), land use and river flow (Sousa et al., 2012; Sousa et al., 2020).

\section{2 | Macroinvertebrate communities}

Differences were detected in the macroinvertebrate communities among rivers. The Rabaçal and Mente rivers belong to the same sub-catchment and share similar macroinvertebrate communities; however, the Tuela and Sabor rivers, being independent sub-basins have distinct macroinvertebrate communities. Therefore, these differences among rivers can be explained by intrinsic differences in environmental conditions among basins (see 4.1) or by a different biogeographical history that could be responsible for a different species composition. However, this last point remains speculative as no biogeographical studies have tested this hypothesis.

The macroinvertebrate communities were not influenced by the MNP, as there were no significant differences between the overall communities as well as richness, abundance, diversity indices and water quality inside, at the periphery and outside the park. Human disturbance is relatively limited in the study area owing to low human population density and the type of activities. Moreover, almost all sites have high heterogeneity of habitats and hydrological conditions that support the presence of high freshwater biodiversity and most of the time an excellent water quality (authors' personal observation). Other studies (Mancini et al., 2005; Heino et al., 2009), also found no differences in macroinvertebrate richness and community composition between protected and unprotected areas in Italy and Finland, respectively

Pearl mussels were recorded in greater numbers inside the MNP. Individuals were smaller, with more juveniles $(<60 \mathrm{~cm})$ inside the park, and consequently higher recruitment, probably related to the fact that more individuals are reproducing in upstream areas (Sousa et al., 2015). Areas with higher pearl mussel density produce more larvae (glochidia) and increase the chances of infestation (Arvidsson, Karlsson \& Österling, 2012). Pearl mussels proliferate in cool, nutrient-poor, well-oxygenated waters, so upstream sites are generally more suitable for their recruitment and survival (Sousa et al., 2013). Also, knowing that Salmo trutta is the unique host of pearl mussel glochidia in the study area, and that the abundance of trout was higher inside the park, this may result in greater glochidial infestation, higher recruitment, and a consequent increase in juveniles. Although not statistically significant, mainly because of the low number of sites surveyed, there was a positive relationship between M. margaritifera and S. trutta abundance. Previous work has shown a positive relationship between the presence of mussels and fish hosts (Arvidsson, Karlsson \& Österling, 2012). No other study has assessed the abundance and population structure of pearl mussels inside and outside PAs, which prevents further comparisons.

\subsection{Fish communities}

Differences in fish communities among rivers are possibly explained by the same intrinsic differences in environmental characteristics or biogeographical history as for the macroinvertebrate communities. Richness and abundance of fish communities were higher outside and at the periphery, when compared with sites inside the park. Results are similar to Chessman (2013) who analysed fish abundance and richness inside and outside Australian PAs. Sites located downstream of the MNP possessed higher richness and abundance, and similar results have been described by Rahel \& Hubert (1991) where fish abundance was positively associated with stream size and position, and negatively with altitude, showing a longitudinal gradient in fish diversity along the river. However, other studies have found no differences in fish richness inside and outside PAs (Silvano, Ramires \& Zuanon, 2009; Penha et al., 2014; Chu, Ellis \& de Kerckhove, 2018) or have found significantly higher richness inside PAs (Abraham \& Kelkar, 2012).

This gradient is responsible for a higher fish diversity and abundance (e.g. S. alburnoides and P. duriense) in downstream sites compared with upstream areas, and this situation is possibly related to a higher availability and quality of resources as well as by higher temperature, greater habitat heterogeneity and flow stability in downstream areas (Grossman et al., 2010). In fact, S. trutta was the only fish species that was more abundant inside the MNP, not only because these mountain rivers of northern Portugal are typically salmonid streams, dominated by $S$. trutta, a species well adapted to the harsh conditions (i.e. low content of nutrients, high discharge, low temperature; Kottelat \& Freyhof, 2007) but also because harvesting brown trout inside the MNP is regulated by law with restrictions on the duration of the fishing season, the number of individuals fished and a minimum catch size (ICNF: https://www. icnf.pt/). Cobitis paludica was not found inside the park, as it has been shown to prefer middle to lower reaches of rivers where it feeds on detritus, chironomid larvae and ostracods (Winfield \& Nelson, 2012).

When analysing species length, all cyprinids (except $S$. carolitertii) were, on average, larger outside the park, which may be related to the higher availability of resources and temperature, and the more stable (and less oligotrophic) conditions that allow higher growth rates. Cobitis paludica were also larger outside the park, but as few individuals were caught, further discussion would be speculative.

\section{5 | CONCLUSION}

The MNP is likely to be more effective at protecting species such as M. margaritifera and S. trutta, than for cyprinid fish species that preferentially colonize more stable and less oligotrophic downstream areas. For macroinvertebrates, in general, no differences were detected. These results were expected because the MNP is located in a high altitude region with headwater streams that are characterized by oligotrophic conditions and fast-flowing waters that favour species such 
as M. margaritifera and S. trutta. This protection given to upstream areas, although not favouring species such as cyprinids, is crucial for maintaining the ecological processes and high biodiversity in the downstream areas. Therefore, given the opportunity (or need) to expand the MNP, we propose an extension to the downstream areas as they display high species richness (some of them with high conservation importance). Besides the possible enlargement of the PA, some management measures should be applied to mitigate the effects of some of the threats in the MNP and surrounding areas, including: control of invasive species such as the signal crayfish Pacifastacus leniusculus and the American mink Neovison vison (Meira et al., 2019; Sousa et al., 2019); improvement of river connectivity by the removal of obsolete physical barriers; better management of the dams to restore more natural river flows and allow fish passage (Schilt, 2007; Sousa et al., 2020); stricter regulation and closer inspection of fisheries (e.g. catch and release or adjustment of minimal length); and an increase in awareness and education programmes in local schools and hunting and fishing associations. Much work remains to be done to achieve a proper system of freshwater protected areas in Portugal and elsewhere (Abell, Allan \& Lehner, 2007; Darwall et al., 2011; Hermoso et al., 2015a), but the information collected in this study will be valuable in implementing future management measures to conserve one of the less human-disturbed regions of Portugal.

\section{ACKNOWLEDGEMENTS}

This work was supported by: i) Programa Operacional Sustentabilidade e Eficiência no Uso dos Recursos (POSEUR-032215-FC-000096) and Instituto da Conservação da Natureza e das Floresta (ICNF) funds under project CP01-MARG-QUERCUS/2018 and ii) European Investment Funds by FEDER/COMPETE/POCI Operational Competitiveness and Internationalization Program, under Project POCl-01-0145-FEDER-006958 and National Funds by FCT -Portuguese Foundation for Science and Technology, under the project UID/AGR/04033/2013." FCT also supported MLL with a doctoral grant (SFRH/BD/115728/2016).

\section{ORCID}

Joana Garrido Nogueira (D) https://orcid.org/0000-0002-5576-3625

Manuel Lopes-Lima (iD https://orcid.org/0000-0002-2761-7962

Ronaldo Sousa (iD) https://orcid.org/0000-0002-5961-5515

\section{REFERENCES}

Abell, R., Allan, J.D. \& Lehner, B. (2007). Unlocking the potential of protected areas for freshwaters. Biological Conservation, 134(1), 48-63. https://doi.org/10.1016/j.biocon.2006.08.017

Abell, R., Thieme, M., Ricketts, T.H., Olwero, N., Ng, R., Petry, P. et al. (2011). Concordance of freshwater and terrestrial biodiversity. Conservation Letters, 4(2), 127-136. https://doi.org/10.1111/j.1755-263X 2010.00153.x

Abraham, R.K. \& Kelkar, N. (2012). Do terrestrial protected areas conserve freshwater fish diversity? Results from the Western Ghats of India. Oryx, 46(4), 544-553. https://doi.org/10.1017/ S0030605311000937

Acreman, M., Hughes, K.A., Arthington, A.H., Tickner, D. \& Dueñas, M.A. (2019). Protected areas and freshwater biodiversity: A novel systematic review distils eight lessons for effective conservation. Conservation Letters, 13(1), e12684. https://doi.org/10.1111/conl.12684

Alba-Tercedor, J., Jáimez-Cuéllar, P., Álvarez, M., Avilés, J., Bonada, N., Casas, J. et al. (2002). Caracterización del estado ecológico de rios mediterrâneos ibéricos mediante el índice IBMWP (antes BMWP). Limnetica, 21(3), 175-185. http://hdl.handle.net/2445/32903

Alba-Tercedor, J. \& Sánchez-Ortega, A. (1988). Un método rápido y simple para evaluar la calidad biológica de las aguas corrientes basado en el de Armitage et al. (1983). Limnetica, 4(5), 51-56.

Anastácio, P.M., Ribeiro, F., Capinha, C., Banha, F., Gama, M., Filipe, A.F. et al. (2019). Non-native freshwater fauna in Portugal: A review. Science of the Total Environment, 650, 1923-1934. https://doi.org/10. 1016/j.scitotenv.2018.09.251

Araújo, M.B., Lobo, J.M. \& Moreno, J.C. (2007). The effectiveness of Iberian protected areas in conserving terrestrial biodiversity. Conservation Biology, 21(6), 1423-1432. https://doi.org/10.1111/j.1523-1739. 2007.00827.x

Arvidsson, B.L., Karlsson, J. \& Österling, M.E. (2012). Recruitment of the threatened mussel Margaritifera margaritifera in relation to mussel population size, mussel density and host density. Aquatic Conservation: Marine and Freshwater Ecosystems, 22(4), 526-532. https://doi.org/10. 1002/aqc. 2240

Baird, I.G. \& Flaherty, M.S. (2005). Mekong River fish conservation zones in southern Laos: Assessing effectiveness using local ecological knowledge. Environmental Management, 36(3), 439-454. https://doi.org/10. 1007/s00267-005-3093-7

Bilz, M., Kell, S.P., Maxted, N. \& Lansdown, R.V. (2011). European red list of vascular plants. Luxembourg: Publications Office of the European Union.

Blanco, J., Bellón, B., Fabricius, C., Roque, F.D.O., Pays, O., Laurent, F. et al. (2019). Interface processes between protected and unprotected areas: A global review and ways forward. Global Change Biology, 26(3), 1138-1154. https://doi.org/10.1111/gcb.14865

Butchart, S.H., Clarke, M., Smith, R.J., Sykes, R.E., Scharlemann, J.P., Harfoot, M. et al. (2015). Shortfalls and solutions for meeting national and global conservation area targets. Conservation Letters, 8(5), 329-337. https://doi.org/10.1111/conl.12158

Cabrita, A., Cunha, R. \& Henriques, P.C. (2000). Parques e Reservas Naturais de Portugal. Lisboa: Verbo.

Chessman, B.C. (2013). Do protected areas benefit freshwater species? A broad-scale assessment for fish in Australia's Murray-Darling Basin. Journal of Applied Ecology, 50(4), 969-976. https://doi.org/10.1111/ 1365-2664.12104

Chu, C., Ellis, L. \& de Kerckhove, D.T. (2018). Effectiveness of terrestrial protected areas for conservation of lake fish communities. Conservation Biology, 32(3), 607-618. https://doi.org/10.1111/cobi.13034

Closs, G., Krkosek, M. \& Olden, J. (2015). Conservation of freshwater fishes. Cambridge: Cambrige University Press.

Collier, K.J. (2011). The rapid rise of streams and rivers in conservation assessment. Aquatic Conservation: Marine and Freshwater Ecosystems, 21(5), 397-400. https://doi.org/10.1002/aqc.1196

Council of the European Communities. (1992). Council Directive 92/43/EEC of 21 May 1992 on the conservation of natural habitats and of wild fauna and flora. Official Journal of the European Communities, L206, 7-50.

Corine Land Cover. (2020). Copernicus Land Monitoring Service. Available at: https://www.copernicus.eu/en [Accessed 1 June 2020]

Covich, A.P., Palmer, M.A. \& Crowl, T.A. (1999). The role of benthic invertebrate species in freshwater ecosystems: Zoobenthic species influence energy flows and nutrient cycling. Bioscience, 49(2), 119-127. https://doi.org/10.2307/1313537

Cucherousset, J., Paillisson, J.-M., Carpentier, A., Thoby, V., Damien, J.-P., Eybert, M.-C. et al. (2007). Freshwater protected areas: An effective measure to reconcile conservation and exploitation of the threatened European eels (Anguilla anguilla)? Ecology of 
Freshwater Fish, 16(4), 528-538. https://doi.org/10.1111/j.16000633.2007.00247.x

Cuttelod, A., Seddon, M. \& Neubert, E. (2011). European red list of nonmarine Molluscs. Luxembourg: Publications Office of the European Union.

Darwall, W.R., Holland, R.A., Smith, K.G., Allen, D., Brooks, E.G., Katarya, V. et al. (2011). Implications of bias in conservation research and investment for freshwater species. Conservation Letters, 4(6), 474-482. https://doi.org/10.1111/j.1755-263X.2011.00202.x

Dudgeon, D. (2019). Multiple threats imperil freshwater biodiversity in the Anthropocene. Current Biology, 29(19), R960-R967. https://doi.org/ 10.1016/j.cub.2019.08.002

Dudgeon, D., Arthington, A.H., Gessner, M.O., Kawabata, Z.I., Knowler, D. J., Lévêque, C. et al. (2006). Freshwater biodiversity: Importance, threats, status and conservation challenges. Biological Reviews, 81(2), 163-182. https://doi.org/10.1017/S1464793105006950

Freyhof, J. \& Brooks, E. (2011). European red list of freshwater fishes. Luxembourg: Publications Office of the European Union.

Gray, C.L., Hill, S.L., Newbold, T., Hudson, L.N., Börger, L., Contu, S. et al. (2016). Local biodiversity is higher inside than outside terrestrial protected areas worldwide. Nature Communications, 7(1), 12306.

Grill, G., Lehner, B., Thieme, M., Geenen, B., Tickner, D., Antonelli, F. et al. (2019). Mapping the world's free-flowing rivers. Nature, 569 (7755), 215.

Grossman, G.D., Ratajczak, R.E., Farr, M.D., Wagner, C.M. \& Petty, J.T. (2010). Why there are fewer fish upstream. American Fisheries Society Symposium, 73, 63-81.

He, F., Zarfl, C., Bremerich, V., David, J.N.W., Hogan, Z., Kalinkat, G. et al. (2019). The global decline of freshwater megafauna. Global Change Biology, 25(11), 3883-3892. https://doi.org/10.1111/gcb. 14753

Heino, J., Ilmonen, J., Kotanen, J., Mykrä, H., Paasivirta, L., Soininen, J. \& Virtanen, R. (2009). Surveying biodiversity in protected and managed areas: Algae, macrophytes and macroinvertebrates in boreal forest streams. Ecological Indicators, 9(6), 1179-1187. https://doi.org/10. 1016/j.ecolind.2009.02.003

Herbert, M.W., McIntyre, P.B., Doran, P.J., Allan, J.D. \& Abell, R. (2010). Terrestrial reserve networks do not adequately represent aquatic ecosystems. Conservation Biology, 24(4), 1002-1011. https://doi.org/10. 1111/j.1523-1739.2010.01460.x

Hermoso, V., Filipe, A.F., Segurado, P. \& Beja, P. (2015a). Filling gaps in a large reserve network to address freshwater conservation needs. Journal of Environmental Management, 161, 358-365. https://doi.org/ 10.1016/j.jenvman.2015.07.023

Hermoso, V., Filipe, A.F., Segurado, P. \& Beja, P. (2015b). Effectiveness of a large reserve network in protecting freshwater biodiversity: $A$ test for the Iberian Peninsula. Freshwater Biology, 60(4), 698-710. https://doi. org/10.1111/fwb.12519

Herremans, M. \& Herremans-Tonnoeyr, D. (2000). Land use and the conservation status of raptors in Botswana. Biological Conservation, 94(1), 31-41. https://doi.org/10.1016/S0006-3207(99)00166-4

Juffe-Bignoli, D., Burgess, N.D., Bingham, H., Belle, E.M.S., de Lima, M.G., Deguignet, M. et al. (2014). Protected planet report 2014. Cambridge: UNEP-WCMC.

Kalkman, V.J., Boudot, J.-P., Bernard, R., Conze, K.-J., De Knijf, G., Dyatlova, E. et al. (2010). European red list of dragonflies. Luxembourg: Publications Office of the European Union.

Keppler, F.W., Hallwass, G. \& Silvano, R.A.M. (2017). Influence of protected areas on fish assemblages and fisheries in a large tropical river. Oryx, 51(2), 268-279. https://doi.org/10.1186/s12898-019-0258-4

Kottelat, M. \& Freyhof, J. (2007). Handbook of European freshwater fishes. Cornol: Publications Kottelat.

Maceda-Veiga, A., Baselga, A., Sousa, R., Vilà, M., Doadrio, I. \& de Sostoa, A. (2017). Fine-scale determinants of conservation value of river reaches in a hotspot of native and non-native species diversity.
Science of the Total Environment, 574, 455-466. https://doi.org/10. 1016/j.scitotenv.2016.09.097

Mancini, L., Formichetti, P., Anselmo, A., Tancioni, L., Marchini, S. \& Sorace, A. (2005). Biological quality of running waters in protected areas: The influence of size and land use. Biodiversity and Conservation, 14(2), 351-364. https://doi.org/10.1007/s10531-004-5355-8

Meira, A., Lopes-Lima, M., Varandas, S., Teixeira, A., Arenas, F. \& Sousa, R. (2019). Invasive crayfishes as a threat to freshwater bivalves: Interspecific differences and conservation implications. Science of the Total Environment, 649, 938-948. https://doi.org/10.1016/j.scitotenv.2018. 08.341

Moorkens, E., Cordeiro, J., Seddon, M.B., von Proschwitz, T. \& Woolnough, D. (2018). Margaritifera margaritifera. The IUCN Red List of Threatened Species 2018: E.T12799A128686456.

Nogueira, J.G., Lopes-Lima, M., Varandas, S., Teixeira, A. \& Sousa, R. (in press) Effects of an extreme drought on the endangered pearl mussel Margaritifera maragaritifera: A before/after assessment. Hydrobiology, 1-11. https://doi.org/10.1007/s10750-019-04103-1

Norris, D., Michalski, F. \& Gibbs, J.P. (2018). Community involvement works where enforcement fails: Conservation success through community-based management of Amazon river turtle nests. PeerJ, 6, e4856. https://doi.org/10.7717/peerj.4856

Oliveira, J.M., Segurado, P., Santos, J.M., Teixeira, A., Ferreira, M.T. \& Cortes, R.V. (2012). Modelling stream-fish functional traits in reference conditions: Regional and local environmental correlates. PLoS ONE, 7(9), e4578. https://doi.org/10.1371/journal.pone.0045787

Penha, J., Fernandes, I.M., Súarez, Y.R., Silveira, R.M.L., Florentino, A.C. \& Mateus, L. (2014). Assessing the potential of a protected area for fish conservation in a neotropical wetland. Biodiversity and Conservation, 23(13), 3185-3198. https://doi.org/10.1007/s10531-014-0773-8

Pimm, S.L., Jenkins, C.N. \& Li, B.V. (2018). How to protect half of Earth to ensure it protects sufficient biodiversity. Science Advances, 4(8), eaat2616. https://doi.org/10.1126/sciadv.aat2616

Rahel, F.J. \& Hubert, W.A. (1991). Fish assemblages and habitat gradients in a Rocky Mountain-Great Plains stream: Biotic zonation and additive patterns of community change. Transactions of the American Fisheries Society, 120(3), 319-332. https://doi.org/10.1577/1548-8659(1991) 120\%3C0319:FAAHGI\%3E2.3.CO;2

R. Development Core Team. (2019). R: A language and environment for statistical computing. Vienna, Austria: R Foundation for Satistical Computing.

Reid, A.J., Carlson, A.K., Creed, I.F., Eliason, E.J., Gell, P.A., Johnson, P.T. et al. (2019). Emerging threats and persistent conservation challenges for freshwater biodiversity. Biological Reviews, 94(3), 849-873. https://doi.org/10.1111/brv.12480

Roux, D.J., Ashton, P.J., Nel, J.L. \& MacKay, H.M. (2008). Improving crosssector policy integration and cooperation in support of freshwater conservation. Conservation Biology, 22(6), 1382-1387. https://doi.org/ 10.1111/j.1523-1739.2008.01080.x

Sanyanga, R.A., Machena, C. \& Kautsky, N. (1995). Abundance and distribution of inshore fish in fished and protected areas in Lake Kariba, Zimbabwe. Hydrobiologia, 306(1), 67-78. https://doi.org/10.1007/ BF00007859

Saunders, D.L., Meeuwig, J.J. \& Vincent, A.C.J. (2002). Freshwater protected areas: Strategies for conservation. Conservation Biology, 16(1), 30-41. https://doi.org/10.1046/j.1523-1739.2002.99562.x

Schilt, C.R. (2007). Developing fish passage and protection at hydropower dams. Applied Animal Behaviour Science, 104(3-4), 295-325. https:// doi.org/10.1016/j.applanim.2006.09.004

Silvano, R.A., Ramires, M. \& Zuanon, J. (2009). Effects of fisheries management on fish communities in the floodplain lakes of a Brazilian Amazonian Reserve. Ecology of Freshwater Fish, 18(1), 156-166. https://doi.org/10.1111/j.1600-0633.2008.00333.x

Sousa, R., Amorim, Â., Froufe, E., Varandas, S., Teixeira, A. \& LopesLima, M. (2015). Conservation status of the freshwater pearl mussel 
Margaritifera margaritifera in Portugal. Limnologica, 50, 4-10. https:// doi.org/10.1111/brv.12244

Sousa, R., Amorim, A., Sobral, C., Froufe, E., Varandas, S., Teixeira, A. et al. (2013). Ecological status of a Margaritifera margaritifera (Linnaeus, 1758) population at the southern edge of its distribution (River Paiva, Portugal). Environmental Management, 52(5), 1230-1238. https://doi. org/10.1007/s00267-013-0117-6

Sousa, R., Ferreira, A., Carvalho, F., Lopes-Lima, M., Varandas, S., Teixeira, A. \& Gallardo, B. (2020). Small hydropower plants as a threat to the endangered pearl mussel Margaritifera margaritifera. Science of the Total Environment, 719, 137361. https://doi.org/10.1016/j. scitotenv.2020.137361

Sousa, R., Nogueira, J.G., Ferreira, A., Carvalho, F., Lopes-Lima, M., Varandas, S. \& Teixeira, A. (2019). A tale of shells and claws: The signal crayfish as a threat to the pearl mussel Margaritifera margaritifera in Europe. Science of the Total Environment, 665, 329-337. https://doi. org/10.1016/j.scitotenv.2019.02.094

Sousa, R., Varandas, S., Cortes, R., Teixeira, A., Lopes-Lima, M., Machado, J. \& Guilhermino, L. (2012). Massive die-offs of freshwater bivalves as resource pulses. Annales de Limnologie - International Journal of Limnology, 48(1), 105-112. https://doi.org/10.1051/limn/ 2012003

Srinoparatwatana, C. \& Hyndes, G. (2011). Inconsistent benefits of a freshwater protected area for artisanal fisheries and biodiversity in a Southeast Asian wetland. Marine and Freshwater Research, 62(5), 462-470. https://doi.org/10.1071/MF10232

Strahler, A.N. (1964). Quantitative geomorphology of drainage basins and channel networks. In: Chow, V. (Ed.) Handbook of applied hydrology. New York: McGraw-Hill. pp. 439-476.

Tachet, H., Richoux, P., Bournaud, M. \& Usseglio-Polatera, P. (2003). Invertébrés d'eau douce: Systématique, biologie, écologie. Paris: CNRS éditions.

Temple, H.J. \& Cox, N.A. (2009). European red list of amphibians. Luxembourg: Office for Official Publications of the European Communities.
Venter, O., Sanderson, E.W., Magrach, A., Allan, J.R., Beher, J., Jones, K.R. et al. (2016). Global terrestrial Human Footprint maps for 1993 and 2009. Scientific Data, 3(1), 160067. https://doi.org/10.1038/sdata. 2016.67

Walters, A.D., Brown, M.A., Cerbie, G.M., Williams, M.G., Banta, J.A., Williams, L.R. et al. (2019). Do hotspots fall within protected areas? A geographic approach to planning analysis of regional freshwater biodiversity. Freshwater Biology, 64(11), 2046-2056. https://doi.org/10. 1111/fwb.13394

Williot, P., Rochard, E., Rouault, T. \& Kirschbaum, F. (2009) Acipenser sturio recovery research actions in France. Biology, conservation and sustainable development of sturgeons. Dordrecht: Springer, 247-263. https:// link.springer.com/book/10.1007\%2F978-1-4020-8437-9\#about

Winfield, I.J. \& Nelson, J.S. (2012). Cyprinid fishes: Systematics, biology and exploitation, 3rd edition. Dordrecht: Springer.

\section{SUPPORTING INFORMATION}

Additional supporting information may be found online in the Supporting Information section at the end of this article.

How to cite this article: Nogueira JG, Teixeira A, Varandas S, Lopes-Lima M, Sousa R. Assessment of a terrestrial protected area for the conservation of freshwater biodiversity. Aquatic Conserv: Mar Freshw Ecosyst. 2021;31:520-530. https://doi. org/10.1002/aqc.3502 